\title{
Archiwalia lubelskie na Liście Krajowej Programu UNESCO „Pa- mięć Świata"
}

W 2021 r. odbyła się 4. edycja programu „Pamięć Polski”, podczas którego na Listę Krajową Programu UNESCO „Pamięć Świata” zostało wpisanych kolejnych 15 obiektów mających szczególne znaczenie dla historii Polski i polskiego dziedzictwa kulturowego. Wśród instytucji kultury i pamięci, z których pochodziły wpisane na Listę Krajową archiwalia, po raz pierwszy w swych dziejach znalazło się Archiwum Państwowe w Lublinie.

$\mathrm{Z}$ tej racji warto przybliżyć istotę i charakter tego programu. UNESCO realizuje szereg programów, których celem jest zabezpieczenie światowego dziedzictwa historycznego i kulturowego oraz jego popularyzacja i promocja. Jednym z takich programów jest właśnie „Pamięć Świata” (Memory of the World). Program ten, realizowany od 1992 r., ma na celu podejmowanie działań służących ochronie i udostępnianiu wielowiekowego dziedzictwa dokumentacyjnego z całego świata. Dziedzictwo to tworzą liczne obiekty o fundamentalnym znaczeniu kulturowym i historycznym. Zalicza się do niego całe zespoły archiwalne i pojedyncze dokumenty o wyjątkowej wartości historycznej oraz zabytki piśmiennictwa o dużym znaczeniu dla kultury, przechowywane w zbiorach archiwów, bibliotek i muzeów, a także inskrypcje czy dokumenty audiowizualne utrwalone na nośnikach analogowych lub cyfrowych. W ramach programu tworzone są trzy rodzaje rejestrów: lista światowa, listy regionalne i listy krajowe.

Od 1997 r. co dwa lata na Listę Światową wpisywane są nowe obiekty zgłaszane przez różne kraje. Obecnie znajduje się na niej 527 pozycji z kilkuset państw ${ }^{1}$. Z kolei na listy regionalne i krajowe są wpisane zabytki dokumentacyjne i piśmiennicze, których znacznie jest istotne dla konkretnych regionów czy państw. Polska również dysponuje swoją listą, na którą wpisywane są obiekty mające kluczowe znaczenie dla polskiej historii, kultury i dziedzictwa dokumentacyjnego, charakteryzujące się przy tym walorem autentyczności, unikalną formą artystyczną i unikatowym charakterem nośnika informacji. Decyzję o wpisaniu na Listę Krajową

1 P. Pietrzyk, Przedmowa, [w:] Pamięć Polski. Lista krajowa programu UNESCO „Pamięć Świata”, Warszawa 2021, s. 6. 
podejmuje Polski Komitet Programu UNESCO „Pamięć Świata”, któremu obecnie przewodniczy Naczelny Dyrektor Archiwów Państwowych dr Paweł Pietrzyk.

Pierwsza edycja programu „Pamięć Świata” w Polsce odbyła się w 2014 r. Wówczas na polską Listę Krajową wpisano 11 obiektów. Podczas drugiej edycji w 2016 r. wpisano kolejne 11 obiektów, a w roku 2018, w 100-lecie odzyskania niepodległości, aż 23 obiekty. Wiele $\mathrm{z}$ wpisanych obiektów to materiały znajdujące się w archiwach państwowych. Można tu wymienić m.in. oryginał Konstytucji 3 maja z 1791 r. (AGAD), dokument lokacyjny miasta Krakowa wystawiony przez księcia Bolesława Wstydliwego w 1257 r. (AN w Krakowie), dokument będący spisem wszystkich aktów prawnych znany pod nazwą Statutu Łaskiego z 1506 r. (AGAD) czy akt fundacyjny Zbiluta z 1153 r., będący jednym z najstarszych zachowanych polskich dokumentów (AP w Poznaniu). Poza archiwami państwowymi wśród jednostek uhonorowanych wpisem na Listę Krajową znajdują się biblioteki, muzea, instytucje kultury oraz organizacje naukowe i społeczno-kulturalne. Wśród tych podmiotów znajdują się także instytucje polonijne przechowujące ważne dziedzictwo dokumentacyjne, będące częścią dziedzictwa narodowego.

W 2021 r., po rocznej przerwie z powodu pandemii koronawirusa COVID19, odbyła się 4. edycja polskiej Listy Krajowej. Archiwum Państwowe w Lublinie w 2020 r. złożyło dwa wnioski nominacyjne na zespoły archiwalne - Trybunał Koronny Lubelski 1579-1811 i Archiwum Ordynacji Zamojskiej ze Zwierzyńca 1581-1944. Decydując się na ich zgłoszenie, uznano, że są to bardzo bogate i rozbudowane pod względem materiału archiwalnego zespoły. Pierwszy zawiera akta związane z działalnością najwyższej instytucji sądowej w Rzeczypospolitej Obojga Narodów, drugi obejmuje dokumentację jednego z największych prywatnych majątków ziemskich w historii Polski. 18 marca $2021 \mathrm{r}$. Polski Komitet Programu UNESCO „Pamięć Świata” podjął decyzję o wpisaniu na Listę Krajową 15 nowych obiektów o szczególnym znaczeniu dla dziejów polskiego państwa i narodu. Wśród nich znalazły się dwa zespoły archiwalne pochodzące z zasobu Archiwum Państwowego w Lublinie, a mianowicie Trybunał Koronny Lubelski i Archiwum Ordynacji Zamojskiej ze Zwierzyńca.

We wniosku nominacyjnym zwięźle scharakteryzowano charakter i działalność Trybunału Koronnego Lubelskiego. Powstał w 1578 r. na sejmie walnym warszawskim, kiedy król Stefan Batory, jako najwyższy sędzia (iudex supremus), zrzekł się dotychczasowych uprawnień w dziedzinie sądownictwa na rzecz stanowego sądu szlacheckiego. Funkcjonował przeszło trzy wieki, do upadku I Rzeczypospolitej, a ostatnia jego sesja odbyła się w roku 1794. Trybunał był najwyższą instancją apelacyjną od wyroków szlacheckich sądów ziemskich, grodzkich 
i podkomorskich, w sprawach zarówno cywilnych, jak i karnych. Sesje Trybunału Koronnego odbywały się w Lublinie i Piotrkowie. Trybunał Lubelski rozpatrywał sprawy wnoszone przez szlachtę i duchowieństwo z Małopolski i województw wschodnich I Rzeczypospolitej, z kolei Trybunał w Piotrkowie zajmował się sprawami z terytorium Wielkopolski, Mazowsza i ziem pruskich.

Akta Trybunału Koronnego pochodzą z lat 1579-1811. Składają się na 1650 jednostek aktowych, co stanowi zaledwie niewielką część produkcji kancelaryjnej tego sądu. Zasadnicza część uległa zniszczeniu podczas powstania warszawskiego we wrześniu 1944 r. Po działalności Trybunału Koronnego Lubelskiego pozostały głównie akta luźne, spośród ksiąg, które były podstawową formą dokumentowania spraw, zachowały się jedynie 4 woluminy. Zachowane materiały są jedną z bardziej znaczących grup akt związanych z sądownictwem szlacheckim okresu przedrozbiorowego. Ważną, bo oddającą przebieg spraw wnoszonych przez szlachtę i duchowieństwo z ziem stanowiących jego właściwość terytorialną. Archiwalia z tego zespołu stanowią unikalne źródło do badań nad historią polskiego sądownictwa w dawnej Rzeczpospolitej. O ich wyjątkowości świadczy też fakt, że przyczyniają się w znacznym stopniu do poznania dziejów magnaterii, stanu szlacheckiego i duchownego ze znacznej części obszaru I Rzeczypospolitej.

Akta Trybunału Koronnego w okresie jego działalności znajdowały się w Lublinie. Księgi przeznaczone do bieżącego urzędowania podczas sesji sądowych przechowywano w kancelarii sądowej, natomiast archiwum - w specjalnie na ten cel wybudowanym skrzydle klasztoru oo. Dominikanów. Z czasem przeniesiono je do utworzonego w 1827 r. Archiwum Akt Dawnych w Lublinie. Niedługo później Komisja Sprawiedliwości uznała, że jako „tyczące się całego kraju” powinny znajdować się w Archiwum Akt Dawnych w Warszawie, dokąd w $1836 \mathrm{r}$. nastąpiło ich prawie kompletne przekazanie. W archiwum warszawskim akta trybunalskie były przechowywane do II wojny światowej, niestety doszczętnie spłonęły 2 września 1944 r. w czasie powstania warszawskiego.

Po wywiezieniu ksiąg trybunalskich do Warszawy, w Archiwum Akt Dawnych w Lublinie pozostały jedynie fragmenty akt, tzw. dissoluta trybunalskie. W 1887 r. na rozkaz władz carskich zostały przekazane do Archiwum Centralnego w Wilnie. Powróciły do Lublina dopiero w 1919 r., kiedy została odbudowana sieć archiwów państwowych po odzyskaniu przez Polskę niepodległości.

Podobnie zwięźle we wniosku nominacyjnym został scharakteryzowany zespół Archiwum Ordynacji Zamojskiej ze Zwierzyńca, będący prywatnym archiwum gospodarczym rodu Zamoyskich. Ordynacja została założona w $1589 \mathrm{r}$. na mocy ustawy sejmu warszawskiego, zatwierdzającej jej organizację i zasady 
dziedziczenia dóbr, opracowane przez kanclerza i hetmana Jana Zamojskiego. W okresie największego rozwoju obejmowała 371 tys. ha, w tym 10 miast, z Zamościem na czele, i 157 innych miejscowości. Funkcjonowała także w okresie zaborów i w dwudziestoleciu międzywojennym, likwidacja nastąpiła dopiero na mocy dekretu Polskiego Komitetu Wyzwolenia Narodowego z dn. 6 IX 1944 r. o reformie rolnej, a jej majątek został rozparcelowany. Archiwum Ordynacji Zamojskiej ze Zwierzyńca zabezpieczono podczas wykonywania dekretu o reformie rolnej. We wrześniu 1945 r. zostało przewiezione do Archiwum Państwowego w Lublinie.

Spuścizna dokumentacyjna Archiwum Ordynacji Zamojskiej ze Zwierzyńca obejmuje akta i mapy i stanowi zespół archiwalny mierzący ponad pół kilometra akt i liczący blisko 40 tys. j.a. Pod względem metrażu i liczby jednostek jest to największe i najbardziej kompletne archiwum ordynackie przechowywane w archiwach państwowych. Archiwum ordynackie sięga początków XIX w., już wówczas powstał rękopis „Opisanie statystyczno-historyczne dóbr Ordynacji Zamojskiej”, który jest ważnym źródłem informacji w badaniach nad dziejami ordynacji. Z kolei na początku XX w. został opracowany inwentarz książkowy zasobu archiwum od XVI do XIX w., który do dziś jest podstawą ewidencji materiałów aktowych.

Akta Ordynacji stanowią kompleksową, unikatową i oryginalną dokumentację administracyjno-gospodarczo-finansową, ukazującą całokształt i ciągłość procesów zachodzących w dobrach Ordynacji Zamojskiej od początku do końca jej istnienia, czyli przez ponad 350 lat. Materiały zgromadzone w zespole szczegółowo dokumentują rozwój społeczny, gospodarczy i finansową kondycję Ordynacji. Zawierają informacje o właścicielach Ordynacji, o rodzie Zamoyskich, urzędnikach zarządzających poszczególnymi składnikami majątku, a także o zróżnicowanej wyznaniowo, stanowo i majątkowo społeczności zamieszkującej ordynackie dobra. Dokumentację aktową uzupełniają bogate zbiory kartograficzne, liczące ponad 3 tys. map dóbr ordynackich, zakładów przemysłowych, linii kolejowych i gospodarki wodnej.

Do innych obiektów, które podczas tej edycji Listy Krajowej zostały uhonorowane wpisami, należą cenne dokumenty z okresu średniowiecza i czasów nowożytnych, m.in. przywilej lokacyjny dla Chełmna z 1251 r., pergaminowy dokument króla Przemysła II z pieczęcią przedstawiającą wizerunek herbu Orzeł Biały, rotulusy z klasztoru Premonstratensów na Ołbinie we Wrocławiu z XIII i XIV w., dokument Kazimierza Wielkiego dla biskupa ormiańskiego we Lwowie z 1367 r., rękopiśmienny zbiór materiałów historycznych 
zwany Tekami Górskiego z XVI w. Zestaw ten uzupełniają zabytki kartograficzne (mapa księstwa pszczyńskiego z 1636 r. i rękopiśmienny atlas zawierający mapy hrabstwa bialskiego z 1781 r.) oraz dzieła naukowe, jakie stanowią traktaty astronomiczne Jana Heweliusza $\mathrm{z}$ lat 1647-1690.

Osobną grupę stanowią dzieła wybitnych twórców polskiej muzyki i literatury. Znalazły się tutaj kolekcja oryginalnych utworów Fryderyka Chopina z lat 30. i 40. XIX w., rękopis Balladyny Juliusza Słowackiego (lata 30. XIX w.) i pozostawiona przez tego autora rękopiśmienna spuścizna z lat 1835-1865. Listę tę wzbogaca rękopis zbioru Krzysztofa Kamila Baczyńskiego W żalu najczystszym, pochodzący z 1942 r.

Listę 15 obiektów zamyka unikatowa kolekcja 93 płyt gramofonowych Polskiego Radia, które są dokumentem dźwiękowym nagranym we wrześniu 1939 r. - pierwszym miesiącu II wojny światowej ${ }^{2}$.

Uroczysta gala wręczenia certyfikatów wpisu obiektów na Listę Krajową Programu UNESCO „Pamięć Świata” odbyła się 10 VI 2021 r. w Belwederze. Uczestniczyli w niej z ramienia władz państwowych Szef Kancelarii Prezydenta RP Grażyna Ignaczak-Bandych, Podsekretarz Stanu w Ministerstwie Kultury, Dziedzictwa Narodowego i Sportu Magdalena Gawin, oraz Naczelny Dyrektor Archiwów Państwowych i Przewodniczący Polskiego Komitetu Programu UNESCO „Pamięć Świata” dr Paweł Pietrzyk. Wszyscy oni w swoich przemówieniach podkreślali rangę programu UNESCO, zarówno dla ochrony i popularyzacji światowego dziedzictwa kulturowego, jak i dla zabezpieczenia i upowszechniania polskiego dziedzictwa dokumentacyjnego ważnego dla zachowania pamięci i tożsamości narodu. Wskazywano przy tym na znaczenie obiektów wpisanych na Listę Krajową jako ważnych świadectw przeszłości i dorobku kulturowego ich twórców. Ozdobą gali był film prezentujący w porządku chronologicznym wszystkie 15 zabytków uhonorowanych certyfikatem. Warto dodać, że ekipa filmowa wcześniej nakręcała poszczególne sekwencje na miejscu, we wszystkich instytucjach, z których pochodziły nagrodzone obiekty. W uroczystości wzięli udział przedstawiciele archiwów, bibliotek i innych instytucji kultury, z których pochodziły uhonorowane obiekty. W imieniu Archiwum Państwowego w Lublinie certyfikaty wpisanych

2 Pełny wykaz uhonorowanych dokumentów i zabytków w poszczególnych edycjach Listy Krajowej jest opublikowany na stronie internetowej programu: $<$ http://www.pamiecpolski.archiwa. gov.pl> [dostęp: 1.11.2021]. 
zespołów Trybunał Koronny Lubelski i Archiwum Ordynacji Zamojskiej ze Zwierzyńca odebrali dyrektor dr Piotr Dymmel i jego zastępca Krzysztof Kołodziejczyk.

Z okazji uroczystego wręczenia certyfikatów Naczelna Dyrekcja Archiwów Państwowych, Polski Komitet Programu UNESCO oraz Organizacja Narodów Zjednoczonych dla Wychowania, Nauki i Kultury zorganizowały wystawę Pamięć Polski. Lista Krajowa Programu UNESCO „Pamięć Świata”, która została otwarta 9 VI 2021 r. w Warszawie przed budynkiem kordegardy. Ekspozycję przygotowała Naczelna Dyrekcja Archiwów Państwowych, a jej kuratorem i autorką komentarzy do poszczególnych obiektów była prof. Anna Krochmal. W jej opracowaniu został także opublikowany katalog wystawy z rzeczowymi opisami, o dużych walorach estetycznych i ciekawej formie edytorskiej. Sama wystawa także przyciągała uwagę swoją nietypową formą artystyczną poszczególne obiekty zostały bowiem zaprezentowane na planszach w kształcie cylindrów o różnej wielkości. Wystawę przygotowano i wyeksponowano w centralnym miejscu Warszawy w celu zaprezentowania szerszemu gronu odbiorców wszystkich obiektów, które w 2021 r. zostały włączone na Listę Krajową Programu UNESCO „Pamięć Świata”. Zaprezentowanie tak znaczącego materiału w przystępnej formie sprzyjało popularyzacji wiedzy o przeszłości, w odniesieniu nie tylko do pokazanych obiektów, ale także szerszego dziedzictwa kulturowego Polski i jego znaczenia w kształtowaniu świadomości historycznej.

Jednym z założeń organizatorów wystawy było pokazywanie jej w miastach, z których pochodziły włączone na Listę Krajową obiekty. Po Warszawie Lublin był drugim miastem, w którym zagościła wystawa. Jej organizacją $\mathrm{z}$ ramienia Archiwum Państwowego w Lublinie zajął się dr Robert Jop. W południe 6 VII 2021 r. na placu Litewskim w Lublinie odbyło się jej uroczyste otwarcie. Obok zaproszonych przedstawicieli władz, instytucji kultury i nauki oraz lokalnych mediów zgromadziła ona wielu mieszkańców miasta. Otwarcia wystawy dokonał dyrektor Archiwum Państwowego w Lublinie dr Piotr Dymmel, który przedstawił podstawowe założenia ekspozycji, jej tematykę, zaprezentowane materiały oraz podkreślił w jej ramach miejsce dwóch zespołów z lubelskiego archiwum. W trakcie wernisażu zwiedzający mogli nabyć katalog przygotowany przez NDAP oraz materiały promocyjne w postaci podkładek z motywami graficznymi z wystawy i komplet pocztówek, na których znalazły się najciekawsze ilustracje z dwóch lubelskich zespołów. Wspomniany zestaw pocztówek został opatrzony wspólnym tytułem Archiwalia lubelskie 
na Liście Krajowej Programu UNESCO „Pamięć Świata”. W jego opracowaniu udział wzięli pracownicy lubelskiego archiwum: Agnieszka Konstankiewicz, Edyta Targońska i Bartosz Staręgowski, którzy dokonali wyboru materiałów oraz przygotowali stosowne opisy i komentarze. W Lublinie wystawa była prezentowana do 29 VII, a następnie została przewieziona do Gdańska.

Piotr Dymmel

\section{Konferencja naukowa Dziedzictwo archiwalne Lublina i Lubelszczy- zny. Ludzie, instytucje, dokumentacja, Lublin, 2-3 grudnia 2021 r.}

Archiwum Państwowe w Lublinie było organizatorem konferencji, która odbyła się w dniach 2-3 XII 2021 r. w Lublinie. Tematem przewodnim konferencji było dziedzictwo archiwalne - jak zauważył podczas otwarcia konferencji Piotr Dymmel, dyrektor Archiwum Państwowego w Lublinie - temat szeroki i ważny. Podkreślił, że dziedzictwo archiwalne Lublina i Lubelszczyzny tworzą nie tylko archiwa państwowe, ich pracownicy i zasób przez te archiwa gromadzony, zabezpieczany i udostępniany, ale też szereg innych instytucji, organizacji i osób prywatnych, których zbiory i kolekcje, mniej znane i mniej rozpoznane, są szczególnie cenne dla budowania i umacniania tego dziedzictwa dla przyszłych pokoleń.

Moderatorem pierwszej części konferencji, poświęconej m.in. zagadnieniom dziedzictwa archiwalnego Lubelszczyzny, był Piotr Dymmel, a referat otwierający obrady, pt. Dziedzictwo archiwalne. Próba definicji terminu i kontekstu jego stosowania, wygłosił Waldemar Chorążyczewski (Uniwersytet Mikołaja Kopernika w Toruniu). Przez świat rozważań na gruncie różnych definicji dziedzictwa archiwalnego i ich zakresu oprowadził uczestników konferencji w bardzo ciekawy sposób. Na przykładzie definicji pojęcia „Lubelszczyzna” pokazał różnice między dziedzictwem archiwalnym a narodowym zasobem archiwalnym. Omówił także zagadnienie wspólnego dziedzictwa archiwalnego, określone w koncepcji UNESCO w 1970 r. W wystąpieniu omówił kryteria definiowania dziedzictwa archiwalnego określone przez mgra Rafała Borychowskiego 